\title{
Prática histórico-crítica, um espaço vazio
}

\author{
José Erasmo Campillo
}

Professor Doutor Livre Docente em Educaçāo. Universidade Federal do Maranhāo.

Considere que a pedagogia histórico-crítica seja um sistema simbólico. Como tal, circunscreve um conjunto de princípios diretores de categorias específicas e essenciais, que se originaram na história social do homem.

Disseminada por agências adequadas, alcançou um espaço -diga-se de passagem- a duras penas,mas consolidou-se, dada a sua verdade e oportunidade. No Brasil, marcou presença; foi a antítese a tudo que fosse autoritarismo. Extrapolando o sistema de educação brasileiro, pois não era essa apenas a sua razão de ser, adornouse do conceito de guardiā do cidadão político e escolar e desmoronou argumentos, pulverizando toda e qualquer pretensão pedagógica, ligada ao recente passado educacional colonizador.

"Basta de inconsciência pedagógica": foi o lema militante.

Calcada em conhecimento estruturado numa linha marxista, tem procurado, através de símbolos apropriados eticamente, apresentar-se e embater conceitos e princípios.

A realidade pedagógica, construída por esse conjunto simbólico, fez escola e vulgarizou uma linguagem chamada progressista, dialética, histórico-crítica. Tal linguagem tem "guetificado" os profissionais que dela não fazem uso. Usa-la em significado estar por dentro, atualizado, não ser tecnicista (uma espécie de câncer pedagógico); o compromisso engajado na luta para tornar o homem personagem de sua historia é avaliado, constantemente, pelas corporaçōes, via uso do discurso históricocrítico. Estruturando tal linguagem, o profissional fica convencido de que está no caminho certo; beatificado pelos símbolos desse sistema, em sua relatividade maldirecionada, sente-se atual. O poder estruturante que no fala BORDIEU (1982: 103) remete os usuários dessa linguagem a compreender o mundo imediato e o mundo social, segundo uma ordem de conhecimento.

No caso do professor, a visão histórico-crítica garante a esse profissional de educação estar atento com sua competência formal, voltada para uma relação dinâmica com o universo político, onde está circunscrito. 
Entretanto, além de conhecimento e forma de comunicação, sabe-se estar reservada aos sistemas simbólicos a função de dominação. Grupos ou classes usam-nos como instrumento de hegemonia sobre os outros. E assim transcorre o sistema simbólico histórico-crítico, atualmente, nas escolas de formação de professores.

A produção teórica derivada desse sistema, desde seu advento, tem ocupado no Brasil, o espaço do silêncio, perpetrado por 64. Discute-se eficazmente e, como nun$\mathrm{ca}$, onde e como o regime autoritário da época bloqueou os aspectos da estrutura e funcionamento escolar. Há precisão nas abordagens e as conclusōes obtidas, em escritos de teses e relatórios de pesquisas do gênero, avolumam-se em quantidade igual à oposta realidade apontada por GOUVEIA (1971), quando evidenciava resultados do sistema simbólico da moda. Agora os temas são outros; o discurso histórico-crítico assentou emergente linguajar simbólico; o mundo, parece, tornou-se mais consciente.

Das preciosas conclusōes a que se tem chegado, usando tal sistema na educação, as contradiçōes evidenciadas, quanto às categorias de currículo, planejamento, abordagem de conteúdo, materiais didáticos, democratização, profissionalização, oportunidades, modos e formas de ensino, dentre outras, em muito têm contribuído para o "pensar educação".

O resultado do uso desse sistema simbólico é esclarecedor quanto às causas dos entraves educacionais. Oriundos do conhecimento então produzido, esses resultados limitam-se à teorização.
Entretanto, há alguma coisa estranha no ar, com relação ao "fazereducacional". Em que pese a eterna desvalorização do magistério e as denúncias relatadas por estudos referenciados por esse sistema, a parte experencial, o palco onde os personagens diretos dessa ação deveriam estar em ebulição, sofrem de paralisia.

$O$ velho sistema tecnicista, moribundo, com a aposentadoria dos mestres-escola, com o fechamento das Escolas Normais ou Institutos de Educação, além do desinteresse das autoridades também pela competência formal, através dos quais o simbolismo e a estrutura desse sistema pudessem resistir, desapareceu. Rei Morto; rei posto. O sistema simbólico histórico-crítico é hegemônico; ocupa espaços, dita conhecimentos.

Mas por que não anda? Mais uma vez ouvimos BORDIEU (1982: 107) "o que constitui o poder das palavras, o poder de as palavras comandarem e ordenarem o mundo, é a crença na legitimidade das palavras e daquele que as profere, uma crença que as palavras por si próprias não podem produzir".

Se não estão conseguindo provocar fatos no "fazer pedagógico", os comunicadores, os estuturadores, os gerentes desse sistema parece que não estão sabendo o que fazer com seu poder simbólico. Não concretizando o discurso, o simbolismo historicamente construído irá historicamente desaparecer, a menos que o rei posto descubra como perpetuar-se.

YOUNG (1975), DOMINGUES (1986), MOREIRA (1992), dentre outros, alem de toda uma comunidade profissional fazem 
coro à circunstância posta em discussão.

Carece, esse sistema, de códigos específicos voltados à operacionalização do seu discurso?

Não é do sistema adequar-se à prática dos seus usuários? Não é por aí sue espaço de discussão? Faz sínteses nesse sentido?

Mas, se é estruturador, e tem poder de uma nova visão de educação e a apresenta, que elementos direciona para os campos do conhecimento que a assumiram?

A resposta a essas perguntas e outras assemelhadas deve ser dada pelos diferentes profissionais que atuam na prática pedagógica, através de pesquisa e estudo.

Didática, prática, metodologia e tecnologia das áreas do conhecimento ensinadas nos $1^{\circ}, 2^{\circ}$ e $3^{\circ}$ graus deverão dar suporte a esse sistema criando o linguajar -leia-se de conhecimento- que o complementam impedindo-o de, historicamente, desaparecer por anemia dos seus operacionalizadores.

Há um espaço enorme evidenciado no simbolismo histórico-crítico para os profissionais de educação, principalmente os de $3^{\circ} \mathrm{grau}$, no que se refere a isso.

Não há hegemonia que se perpetue, se seus detentores não souberem mostrarse à altura do sistema que a concebeu.

Parece faltar convicção do discurso, nos seus defensores, quando têm que enveredar pelo campo da ação concreta. Con- vicção, acreditamos não falte, mas sim, a experiência na ação pedagógica como fato, pois é dos sistemas não resistir à falta de canais adequados de comunicação.

O problema parece, então, duplamente ligado aos recursos humanos de $3^{\circ} \mathrm{grau}$, responsáveis pela formação do magistério:

$1^{\circ}$ - Não ter, não buscar experiência, na área que se ensina, é não conferir verdade às palavras, que se defendem; o sujeito construtor do conhecimento fica inseguro.

$2^{\circ}$ - Não criar códigos operacionais para uma comunicação eficiente desse sistema ao nível dos alunos, futuros professores, é querer enfiar pela garganta dos mesmos o discurso (códigos teóricos) reduzindo sem autocrítica uma realidade pedagógica tão igual ao que sempre se condenou.

Uma dominação igual, só que anêmica, sem convicção e vazia, é pior que um tecnicismo alienante. É isso o que passa pela cabeça dos alunos, quando têm mestres pouco convincentes na prática.

Está na hora de se escrever mais sobre a parte operacional do simbolismo histórico-crítico; de pesquisá-lo nas circunstâncias a que se propōe; de corrigir a sua prática se necessário, sem medo de ser chamado de tecnicista histórico-crítico.

A outra saída é deixar como está, confundindo-se os alunos com a retórica ou doutrinação baratas que não dignificam a classe do magistério, só o charlatanizam. 


\section{Referências bibliográficas}

BORDIEU, P. O poder simbólico. In: Sociologia da educação. Lisboa: Horizonte, 1982.

CAMPELLO, J.E. e outros. Coerência prática de um discurso teórico. Brasília: CNPq, 1995

DOMINGUES, J.L Interesses humanos e paradigmas curriculares. Revista brasileira de estudos pedagógicos, Brasília, 67, 1986.

GOUVEIA, A.J. A pesquisa educacional no Brasil. Cadernos de pesquisa, São Paulo, n. 1, 1971.

MELLO, G.N. Escolas eficazes. In: Gestão escolar. Brasília: IPEA, 1994.

MOREIRA, A.F.B. Escola, currículo e a constituição do conhecimento. In: SOARES, Magda Becker (org.) e outros. Escola básica. Campinas: Papirus, 1992.

YOUNG, M. Curriculum change: limits and possibilities. In: The Curriculum The Doris Lee Lectures. Londres: University of London, 1975. 